\title{
Universiteit
}

Leiden

The Netherlands

\section{Human Cloning Through the Eyes Of Muslim Scholars: The New Phenomenon Of The Islamic International Religioscientific Institutions} Ghaly, M.M.I.

\section{Citation}

Ghaly, M. M. I. (2010). Human Cloning Through the Eyes Of Muslim Scholars: The New Phenomenon Of The Islamic International Religioscientific Institutions. Zygon: Journal of Religion And Science, 45(1), 7-35. Retrieved from https://hdl.handle.net/1887/16539

Version: $\quad$ Not Applicable (or Unknown)

License: $\quad$ Leiden University Non-exclusive license

Downloaded from: $\quad$ https://hdl.handle.net/1887/16539

Note: To cite this publication please use the final published version (if applicable). 


\title{
Muslim Perspectives on Cloning
}

with Mohammed Ghaly, "Human Cloning through the Eyes of Muslim Scholars"; Farrokh B. Sekaleshfar, "A Critique of Islamic Arguments on Human Cloning"

\section{HUMAN CLONING THROUGH THE EYES OF MUSLIM SCHOLARS: THE NEW PHENOMENON OF THE ISLAMIC INTERNATIONAL RELIGIOSCIENTIFIC INSTITUTIONS}

\section{by Mohammed Ghaly}

\begin{abstract}
In the wake of the February 1997 announcement that Dolly the sheep had been cloned, Muslim religious scholars together with Muslim scientists held two conferences to discuss cloning from an Islamic perspective. They were organized by two influential Islamic international religioscientific institutions: the Islamic Organization of Medical Sciences (IOMS) and the International Islamic Fiqh Academy (IIFA). Both institutions comprise a large number of prominent religious scholars and well-known scientists who participated in the discussions at the conferences. This article gives a comprehensive analysis of these conferences, the relation between science and religion as reflected in the discussions there, and the further influence of these discussions on Muslims living in the West. Modern discussions on Islamic bioethics show that formulating an Islamic perspective on these issues is not the exclusive prerogative of religious scholars. Formulating such perspectives has become a collective process in which scientists play an essential role. Such a collective approach strengthens the religious authority of Muslim scholars and makes it more influential rather than undermining it.
\end{abstract}

Keywords: $\quad$ cloning; collective interpretation (ijtih $\bar{a} d$ jamāä); Islamic bioethics; Muslims in the West; science and religion

Mohammed Ghaly (http://www.hum.leiden.edu/religion/organisation/institute-staffl ghaly.html) is an assistant professor of Islamic Studies at Leiden University, Faculty of Humanities, Leiden Institute for Religious Studies, Matthias de Vrieshof 1, Postbox 9515, 2300 RA Leiden, The Netherlands; e-mail m.ghaly@hum.leidenuniv.nl. 
Contrary to the case in the Western world, bioethics is not an independent field of study within the Islamic tradition but a branch of Islamic law and ethics. Thus, the authorities are mainly Muslim religious scholars. Lacking direct references in the primary sources of Islam, especially the Qur'ān (the Holy Scripture of Muslims) and the Sunna (sayings, deeds, and approvals of the prophet of Islam), the chief task of these scholars is to give an "independent reasoning or interpretation, known in the Islamic tradition as ijtihad)" of what these sources would imply about different bioethical issues (Qaradāwì 1994, 10-12).

Recognizing the complex nature of bioethics and the specialized knowledge of modern sciences required for this purpose, Muslim religious scholars began in the 1980s to study bioethics in cooperation with biomedical scientists, because the overwhelming majority of modern Muslim religious scholars are trained neither in biomedical sciences nor in the Western languages in which the up-to-date scientific studies are available. Such collaboration between scientific and religious scholars takes place mainly within three international institutions consisting of experts in Islamic sciences and biosciences. The Islamic Organization of Medical Sciences (IOMS), based in Kuwait and established officially in 1984, is the most influential. This institution is exclusively occupied with studying bioethical issues from an Islamic perspective ( $h t t p: / / w w w . i s l a m s e t . c o m / i o m s / i n d e x . h t m l)$. IOMS coordinates with two other authoritative religious institutions that pay occasional but not exclusive attention to bioethics. One is the Islamic Fiqh Academy (IFA), established in 1977, which is affiliated with the Muslim World League and based in Mecca, Saudi Arabia (http://www.themwl.org/). The other is the International Islamic Fiqh Academy (IIFA), established in 1981, based in Jeddah, Saudi Arabia, and affiliated with the Organization of Islamic Conference (http://www.fiqhacademy.org.sa/). These institutions are exclusive neither for one specific Islamic country nor for a specific trend within the Islamic tradition. Scholars from different Muslim countries with Sunni and Shìi backgrounds function as members and experts in these institutions. Therefore, religious-ethical advice (fatwas) given by these institutions usually enjoy wide acceptance among individual Muslim scholars at large, and this acceptance trickles down to Muslims at the grassroots level.

\section{Current Research LaCuna, Main Hypotheses, AND QUESTIONS OF THIS STUDY}

The few available studies on Islamic bioethics focus mainly on the contributions of individual Muslim scholars and pay little or no attention to the contribution of these institutions. The still fewer studies that do pay attention to these institutions either make fragmentary references to one or two papers submitted by the religious scholars during one of the conferences or 
focus on the final standpoints adopted in these conferences. The collective approach, which is the unique character of these institutions, is almost completely neglected. This is the case with the issue of cloning in Islam, despite the presence of several critical researches that have touched upon this topic (Eich 2006, 291-309; al-Hayani 2008, 783-95). A comprehensive analysis of these conferences, the relation between science and religion as reflected in the discussions there, and the further influence of these discussions on Muslims living in the West are still clear lacunae in modern research on Islamic bioethics.

The aforementioned institutions regularly organize international conferences in which both religious scholars and biomedical scientists participate. Participating scientists are asked beforehand to write papers on a specific bioethical topic. The papers usually are written in Arabic, with no scientific jargon or complexities, so that they are accessible to the religious scholars. The papers are distributed among the religious scholars before the conference (see for instance, 'Awadì and al-Jundì 1997, 49, 50, 125, 390; Majallat 1997, 142). This collaboration between religious scholars and scientists falls within the modern phenomenon of "collective ijtihād" where formulating an Islamic viewpoint on a specific issue is not the prerogative of religious scholars alone.

The collective ijtih $\bar{a} d$ practiced in these institutions has not yet received due attention from modern researchers. In this type of $i j t i h \bar{a} d$, an important part of the religious authority of Muslim scholars has been waived for the sake of the scientists. As we shall see, religious scholars base many of their conclusions first on information provided by the scientists, and only thereafter do they look into the sources of Islam, the Qur'ān and Sunna. Additionally, the way these scholars approach the textual references in the sources is highly influenced by information provided by the scientists. Keeping in mind that the scientific advancements that raise the (bio)ethical questions are developed in the West, Muslim scientists base their information almost exclusively on Western studies. Noteworthy in this regard is that information provided by Muslim scientists constitutes both a scientific and (bio)ethical part. Muslim religious scholars are not less interested in these bioethical debates in the West than in the scientific information. The point is that Islamic bioethical perspectives are not shaped by Islamic sources alone. Scientific and bioethical information, largely based on Western studies, plays a significant role. However, this vivid interaction between science and religion as exemplified in the collective $i j t i h \bar{a} d$ is missing in current research. Presenting the opinions of religious scholars apart from the contributions of scientists creates the wrong impression that these scholars are formulating their perspectives in a vacuum.

Another important element of the collective $i j t i h \bar{a} d$ is its ability to combine diversity on one hand and unification on the other. The diversity is shown by the different and sometimes contradicting opinions expressed in 
the conference papers submitted by religious scholars. Intensive discussions take place among religious scholars and scientists during each conference in order to eventually forge the various opinions into a unified bioethical standpoint upon which the participants agree. The fragmentary references to contributions of these institutions in the field of bioethics always have the problem of focusing on one of these two elements-either diversity, by quoting one of the papers submitted by a religious scholar, or unification, by citing the final standpoint adopted at the end of the conference. To my mind, such a piecemeal approach does not do justice to the richness of the collective ijtih $\bar{a} d$ that combines diversity with unification.

Another issue needing elaboration is the influence of the collective ijtih $\bar{a} d$. As I show in a later section, standpoints adopted by these institutions are highly influential among Muslims_-not only those living in the Muslim world but also those living as religious minorities in the West. The standpoints also seem to appeal to a number of Western physicians and bioethicists. Thus, collaboration between scientists and religious scholars does not undermine the authoritativeness of the religious scholars but rather is a strengthening factor. Additionally, this type of $i j t i h \bar{a} d$, to my mind, should not be interpreted as a fragmentation of the religious authority within Islam but rather as a unification of different powers.

This article, in studying the discussions of Muslim scholars and scientists within these institutions on cloning, handles a number of central questions in these discussions: Does cloning mean creating, thus challenging the belief that God is the only Creator? Does cloning humans in particular undermine the uniqueness of humans, as intended by God, compared to other creatures? What are the main ethical reservations about cloning and the main benefits, if any? At the end, is cloning an ethical practice? Is there a difference, ethically speaking, between cloning plants or animals and cloning humans, and why or why not?

For a systematic presentation of the proceedings of two conferences and their wide geographical influence, this article begins with an introduction to the conferences and the cloning issue followed by three main sections. "Science and Religion in the Context of Cloning" elaborates on the relation between science and religion in the modern Islamic context as reflected in the proceedings of these conferences. Special attention is given to the identity and the role of Muslim scientists as "informants" for religious scholars and the Western scientists and ethicists these Muslim scientists quote. "Religious Scholars: Opponents and Proponents" focuses on the other group of participants, namely, religious scholars, their identity, their arguments against and for cloning, and the final positions adopted in each conference. "Further Developments: Muslims in the West" is dedicated to studying the further developments concerning Islamic perspectives on cloning with the main focus on these developments relevant to Muslims living in the West. 


\section{ClOning AND THE TwO CONFERENCES IN FoCUS}

The successful cloning of the sheep Dolly, announced in February 1997, captured the world's attention and triggered a huge debate among politicians, scientists, and ethicists in the West, where the reaction was immediate and almost comprehensively hostile. Bill Clinton, then president of the United States of America, was quoted as saying, "There is virtually unanimous consensus in the scientific and medical communities that attempting to use cloning techniques to actually clone a human being is untested and unsafe and morally unacceptable" (Frey and Wellman 2003, 384). More or less the same opinion was offered in other Western countries and also by Dr. Hiroshi Nakajima, Director General of the World Health Organization, who considered the use of cloning for the replication of human beings "ethically unacceptable" (Frey and Wellman 2003, 384-85). The Muslim world was no exception. However, the first reaction came from the circles of the scientific and religious elite and not from the political milieu. Even when human cloning moved to the United Nations agenda later on, Muslim countries expressed their need to consult their religious communities before taking an official action (Banchoff 2008, 288).

As for the reaction of the scientific elite, Muslim scientists and religious scholars from the whole Muslim world held two large-scale conferences, both organized jointly in 1997 by two of the aforementioned institutions, IOMS and IIFA. One took place in Casablanca, Morocco, 14-17 June; the other was in Jeddah, Saudi Arabia, 28 June-3 July. The Casablanca conference was organized by IOMS in cooperation with IIFA, the Islamic Educational, Scientific and Cultural Organization (ISESCO), the Regional Office for the Eastern Mediterranean of the World Health Organization, and Al-Hasan II Institute for the Scientific and Medical Researches on Ramadān and Health. The Jeddah conference was organized by IIFA. Papers submitted to these two conferences, the discussions that took place among the attendants, and the recommendations of each conference appeared in two separate voluminous publications ('Awadì and al-Jundì1997; Majallat 1997, 131-432).

The Casablanca conference was attended by eighty-three persons including religious scholars, physicians, pharmacists, psychologists, and political figures. Fourteen were Muslims living in the West: twelve from the United States, one from Canada, and one from Germany. The rest came from Islamic countries such as Kuwait, Morocco, Saudi Arabia, Jordan, Egypt, Oman, Tunisia, and Qatar ('Awadì and al-Jundì 1997, 541-48). Fourteen papers were presented in this conference that handled the issue of cloning not only from religious perspectives but also from biomedical, philosophical, social, psychological, and legal perspectives ('Awadì and alJundi 1997, 6-7). The Jeddah conference was attended by twenty-four persons, almost all of them affiliated with IIFA as members or experts. The 
overwhelming majority were religious scholars. Five papers were presented during this conference; three of them handled cloning from a religious perspective and the others from a scientific viewpoint (Majallat 1997, 133, 359-414).

One of the main differences between these two conferences is the absence of the Shì ì perspective in the Casablanca conference. This is despite the regular presence and participation of different prominent Shì i scholars in the IOMS activities. The well-known Iranian Shìi scholar Shaykh Muhammad al-Taskhìri, invited but unable to attend, nominated Shaykh Hasan al-Jawāhirì to replace him. However, he also did not manage to join the conference (Majallat 1997, 316). Al-Taskhini did participate in the Jeddah conference and submitted a paper in favor of cloning.

\section{SCIENCE AND RELIGION IN THE CONTEXT OF ClONING}

Although the two conferences focused specifically on cloning, the discussions give an impression about the relation between science and religion in general as seen by the participants. For instance, participants viewed the issue of cloning and its ethical complications as a serious challenge that necessitates collaboration between specialists in the biomedical sciences and those in the Islamic sciences. In his inaugural speech during the Casablanca conference, Muhammad al-Habìb Ibn al-Khūja, secretary general of the IIFA, elaborated on this. He argued that the main task of specialists in the Islamic sciences is to search the main sources of Islam, the general maxims in Islamic religious law (Sharī'a), the spirit of the Sharía, and the contentions of early Muslim scholars, keeping in mind the public interests recognized by the Sharía. Specialists in the biomedical sciences are entrusted with explaining the scientific and the technical sides of these issues to religious scholars. With this help from the scientists, Ibn al-Khüja added, religious scholars will be able to ponder these difficult issues and come up with Sharía-conforming conclusions. According to him, a positive attitude toward the collaboration of these two groups is a deeply rooted tradition throughout Islamic history. As an example, he referred to physician Ishāq b. 'Alì al-Ruhāwì, who wrote Adab al-tabìb (the practical ethics of the physician), the seminal work on Islamic medical ethics in the medieval period ('Awadì and al-Jundì 1997, 47-48; see also al-Ruhāwì 1992; Levey 1967). Al-Ruhāwì spoke of two indispensable things in life: the religious books and the science of medicine. The former is necessary for ethics and education, whereas the latter is important for maintaining one's body and health. Ibn al-Khūja added that Islamic history includes Muslim scholars who mastered both religious and biomedical sciences, such as the Andalusian scholar 'Abd al-Malik b. Habib al-Albìrì al-Qurtubì (d. circa 853), who wrote books both in Islamic law and in medicine. Ibn al-Khūja expressed his gladness and satisfaction with the current collaboration between reli- 
gious scholars and scientists as reflected in the proceedings of the Casablanca conference ('Awadì and al-Jundì 1997, 47-50).

Who are the scientists whose contributions are appreciated by Ibn alKhūja and other religious scholars?

The Identity of the Scientists. The six scientific papers presented during the Casablanca conference were written by five scientists: Hassān Hathūt (Hassan Hathout), 'Umar al-Alfi (Omar Alfi), Sadiqa Al-'Awadì (Sadika Al-Awadi), Ahmad al-Jundì (Ahmed El-Gendi), and Muhammad alYashyawi. Hathout, who presented two papers, is an Egyptian physician and ethicist who was born on 23 December 1924 and received his diploma in obstetrics and gynecology from Cairo University in 1948. He did postgraduate studies at the Royal College of Surgeons and received a Ph.D. degree from the University of Edinburgh. In 1966 he moved to Kuwait and in 1973 cofounded the Kuwait University Medical School, where he taught until 1988. In 1984 he cofounded the IOMS also in Kuwait. In 1989 Hathout moved to the United States in order to make Dawah (propagating Islam) among the American people. His interest in this stemmed from the amount of negative distortions that were present in America at that time. The center of his religious activities was the Islamic Center at Los Angeles where he functioned as its head. In addition to being a scientist and ethicist, he is a bicultural and bilingual poet, speaker, thinker, and writer (Twair 2008, 26-27; http://hassanhathout.com/aboutl index.html).

Alfi is an Egyptian-born American pediatric geneticist who received his medical degree from Cairo University. He is the director of Alfigen, The Genetics Institute in Pasadena, California, which he founded in 1982. He was affiliated with the department of Pediatrics of the School of Medicine, University of Southern California, and Genetics Institute, Alhambra, California (Alfi et al. 1971, 423; Roe and Alfi 1977, 55; Jenkins et al. 1985, 297). Dr. Alfi and his wife Azmeralda founded the New Horizon School, an independent Islamic school, in 1984. They have been active in the interfaith community promoting understanding and family values among different faith groups (http://www.iclcf.org/family_history_fair.pdf). They also have established the Omar and Azmeralda Alfi endowed chair in Islamic law at the University of California, Los Angeles (UCLA), School of Law, which is now occupied by Professor Khaled Abou El Fadl (http:// www.campus-watch.org/articlelid/2909).

Al-Awadi, MD (Dublin), FRCP (Edin.), is the director and consultant of the Kuwait Medical Genetics Centre, Ministry of Health. Founder of the Kuwait Medical Genetics Centre, she is a well-known geneticist in the Arab world with a long list of publications (Awadi et al. 1985, 483-86; 1986, 384-88; Al Fadhli et al. 2008, 512-16). She is responsible for the creation of the Kuwait Down Syndrome Society and the Down Syndrome Parents League. She received the WHO Down Syndrome Research Prize 
for conducting valued research in this field, promoting and establishing specialized centers to treat patients with Down Syndrome (http:// www.cags.org.aelaboutcags.html).

El-Gendi is an Egyptian pharmacologist who has worked in Kuwait for a long time and currently is the secretary general assistant of the IOMS. He has coedited most of the IOMS publications from its beginning to the present. Finally, al-Yashyawi was presented as a lecturer in the Faculty of Sciences, Ibn Tofail University, Morocco. ${ }^{1}$

During the Jeddah conference, two scientific papers were presented. The first was one of El-Gendi's that he had read during the Casablanca conference. The second was written by Sālih 'Abd al-Azizz al-Kurayyim, an associate professor of experimental embryology, Faculty of Sciences, King Abdulaziz University, Kingdom of Saudi Arabia.

Karl Giberson, director of the forum on Faith and Science at Gordon College in Wenham, Massachusetts, in a recent book deplores the current tense relation between scientists and theologians in America, which, he argues, was not the case in the past. He writes that "theology and science reside in different buildings on opposite corners of university campuses separated by armed guards and barbed wire" (Giberson 2008, 22). Why is this not the case between scientists and religious scholars at Islamic institutions? Of course, a long list of arguments could be advanced in response to this question about the essential differences between Islam and Christianity, sociopolitical differences between America and the Muslim world, and so forth. However, the focus here is the identity of these scientists.

Scrutinizing their identity, we can trace a number of common characteristics that surely have played roles in smoothing their relation and cooperation with religious scholars. One of these is their sympathy with Islam. Hathout left for America to propagate for Islam and better its image there, Alfi funded an endowed chair in Islamic law at UCLA, and al-Kurayyim is involved with the Commission on Scientific Signs of Qur'àn \& Sunnah, which has as one of its aims to use the scientific signs in the Qur'an and Sunna as a means of propagating Islam (http://www.nooran.org/en/About_us $. h t m)$. These scientists' contributions in such conferences are also done free of charge (as physician Muhammad 'Alì al-Bār, a regular participant, told me in a personal interview in Jeddah, Saudi Arabia, in January 2009). They participate, al-Bār said, out of their feeling of responsibility toward their religious beliefs.

Another important common characteristic is that these scientists are "innocent" in that they are telling about technological advancements done by Western scientists. They speak about something that happened beyond their control, for which they cannot be held responsible. Finally, these scientists seem familiar with what is going in the West not only in the academic sense but also in the sociocultural sense, a side that highly interests the religious scholars. Besides the fact that almost all of these scientists 
received different academic degrees from well-known Western universities, some of them, including Hathout and Alfi, spent decades of their lives in the United States.

The list of biomedical scientists who participated in these conferences are not limited to the aforementioned ones who submitted papers. Many other prominent biomedical scientists attended the conferences, especially the one in Casablanca, and participated actively in the discussions ('Awadi and al-Jundì 1997, 541-48; Majallat 1997, 133, 359-414).

What was the exact role of these scientists in these conferences?

The Multidimensional Role of the Scientists. The contribution of Muslim scientists in these conferences was not limited to that of giving a simplified overview of cloning. A three-dimensional role can be traced.

1. The first dimension was that of paving the way for religious scholars to discuss human cloning, a technological advancement not yet realized. Discussions among religious scholars on human cloning raise an important methodological question: Why should we discuss this technology when it is not yet realized? In early Islamic law, there was a trend toward hypothesizing nonexistent problems and then trying to come up with Sharíacompliant solutions. This trend, termed in the Islamic tradition the hypothesizers (al-ara'aytiyyūn), was seen by some Muslim scholars as an abhorrent practice because it wastes precious time that should be used to discuss already existing problems. Holding large-scale conferences in order to study human cloning, which might or might not ever happen, could fall in this category. Participating scientists were aware of this potential objection. The main explanation came from Hathout, who wrote an article about "cloning and the hypothesizers" (1997b, 91-100) in which he elaborates on this point and argues that the approach of the classical al-ara'aytiyy $\bar{u} n$ is similar to the "Byzantine discussions" in which the Byzantines would delve into superstitious debates while their enemies were at the gates. However, Hathout argues, the approach of the hypothesizers, though notorious in the past, is needed in modern times. Citing the example of test-tube baby technology, Hathout writes, "The last few decades taught us that much of what falls under the scientific fiction changes within a short period of time into factual reality and a normal practice" (p. 93). Following the traditional approach and studying exclusively issues that already exist would render ethicists and religious scholars unable to cope with scientific advancements that develop in light-speed tempo (Hathūt 1997b, 93). An important issue Hathout and other scientists raise is that although human cloning is not yet realized, it is possible that it will take place in the near future (Hathūt 1997a, 167; 1997b, 94; Kurayyim 1997, 306). Al-Yashyawì argued that human cloning will inevitably happen $(1997,104)$.

Had the scientists come to a different conclusion, I believe that human cloning would not have received this level of attention, and maybe none at 
all, from Muslim religious scholars (see Wâsil 1997, 420-23). To give an example of how things would be if scientists agreed that human cloning is practically impossible, I refer to the opinion of the Jordanian scholar 'Abd al-Salām al-Abbādì. During the Jeddah conference al-'Abbādì said that he had discussed this issue with a prominent physician who assured him that human cloning is almost impossible. Given that opinion, al-'Abbādi wondered why we should occupy ourselves with the issue (Majallat 1997, 404). Clearly, however, the scientists who presented papers managed to make the participating religious scholars think differently. Additionally, the scientists were skeptical about the possibility of cloning organs or tissues only without using embryos. Hence, therapeutic cloning was almost a nonissue for the religious scholars, and no reference was made to this type of cloning in the final declarations of the conferences.

2. The second dimension of the biomedical scientists' role had to do with providing the religious scholars with scientific and technical information about cloning as a new biological advancement. The material was offered in a simple way and presented in the Arabic language. Introductory information was provided about a number of basic concepts the understanding of which was deemed necessary to know exactly what cloning is, such as gene, cell, DNA, and genetic engineering (Hathūt 1997a, 7881; Yashyawi 1997, 105-11). Also, historical information about cloning as a concept was hinted at with special emphasis on seminal experiments such as those on frogs conducted in the 1950s by Robert Briggs and Thomas King. Other papers analyzed the experiments on monkeys conducted in 1997 by scientists at Oregon University and finally on sheep as epitomized in Dolly (Jundì 1997b, 239-47; Kurayyim 1997, 303-6). Explanations of the main types of cloning and what each type means was a recurrent point in the papers (Jundì 1997b, 241-44; Hathūt 1997a, 81-84; Kurayyim 1997, 281-302).

3. The third dimension was mapping the ethical standpoints adopted by different countries, organizations, or individual scientists in the West. Broadly speaking, there was serious interest in knowing these standpoints. Reference was made to a resolution of the British House of Commons that banned cloning shortly before the Casablanca conference took place. In his inaugural speech during the conference, 'Abd al-Azizz al-Tuwijrì, general director of the ISESCO, Morocco, referred to this resolution and said that such a resolution has its implications and its significance as well ('Awadi and al-Jundi 1997, 61). The WHO press release issued 11 March 1997 was appended to El-Gendi's paper (Jundì 1997a, 156-59). The scientists stressed that this dimension had to be accomplished not only simply but also as honestly and objectively as possible. The religious scholars thus would be able to formulate the Islamic perspective without being under any direct or indirect pressure ('Awaḍi and al-Jundì 1997, 13). 
The Moroccan pedagogue Muhammad Yatim submitted a paper to the Casablanca conference on the ethical and social consequences of human cloning. It analyzed the relation between science and religion in the West, and he adopted a generally negative tone toward the West. He stated that modern sciences in the West originated and developed in a context where a clear tension prevailed between science and religion. Modern sciences rejected any role for ethics or religion in guiding science. That, Yatim argued, is why many results of science and technology put the environment and the human being at risk. He referred to contraceptive methods that, despite positive effects such as family planning, implied great evils such as spreading dissoluteness (Yatim 1997, 229-31). In indirect response to this paper and without naming the author, Muhammad Haytham al-Khayyạt (vice-director of the WHO Regional Office for the Eastern Mediterranean) made critical remarks about the required objectivity while presenting the image of scientific advancements in the West and its ethical consequences. To him, a certain degree of nonobjective exaggeration prevailed in some presentations, as if the presenters wanted to terrify the religious scholars. He argued that giving the impression that almost all scientific advancements in the West would imply an infringement upon ethical principles is beyond objectivity. Referring to contraceptive methods, al-Khayyăt said that they did not create the sexual revolution in the West because this revolution began long before these methods were discovered.

In his paper submitted to both conferences, El-Gendi divided the main arguments circulating in the West on cloning into proponents and opponents. His focus was individual scientists rather than governments, and he elaborated further on the arguments of each group. El-Gendi's list of those opposed to cloning starts with the one he names as the prominent geneticist and the Nobel laureate in biology, Watson (Jundì 1997b, 249) - referring to James D. Watson, the DNA pioneer and 1962 Nobel Prize winner who testified before the United States Congress in 1971 on the subject of human cloning (President's Council on Bioethics 2002, 25). In light of the prediction made by two of his colleagues, Robert Edwards and Patrick Steptoe, that their research in 1972 would result in the birth of the first baby conceived in a test tube, Watson argued that decisions of such importance as test-tube conception and human cloning should not be left to scientists alone. Otherwise, the free choice of the public will one day suddenly be gone (Watson 1971, 50-53; Poland and Bishop 2002, 305-24). El-Gendi quoted Watson as saying about cloning, "This act will lead to a considerable disturbance in the evolution and this means an everlasting chaos ... it is extremely dangerous to deprive your child of feeling himself as an individual and impose something on him which he might not be satisfied with because of your sheer interference in the natural course of events" (Jundì 1997b, 249). Of course, concern over disturbing evolution 
is not unique to cloning but has been cited with respect to germ-line genetic engineering - it actually has stopped that technology from being used. Additionally, El-Gendi referred to Leon Kass, a specialist in molecular biology, who was quoted as saying, "One of the possible dangers of such a practise for humankind is that eventually some of its individuals would overrule whereas the others would die out" (Jundi 1997b, 249-50). Kass (b. 1939), known as one of the chief opponents of human cloning (Kass and Wilson 1998), functioned as a member of the President's Council on Bioethics whose members were appointed by George W. Bush (http:// www.bioethics.gov/about/kass.html). Dr. Daniel Callahan, El-Gendi added, wrote an extensive article on this topic and expressed his agreement with Kass where he argued that such irresponsible practices might deprive us of our humanness to a terrifying degree. Callahan (b. 1930) is a stern opponent of human cloning who has held fast on this point since the 1970s and sticks to it because he believes that since then no new arguments have been advanced in favor of cloning (Callahan 2001, 104-5). Besides jeopardizing the uniqueness of human beings, opponents of human cloning refer to a theological argument, namely, that of playing God (Jundì 1997b, 250).

As for proponents, El-Gendi mentioned the pioneer in modern biomedical ethics Joseph Fletcher (1905-1991) (on him, see Steinfels 1991, 25). Although Fletcher is known as a theologian and ethicist, El-Gendi presented him as an important biologist who argued that conducting scientific research is ethical as long as human beings enjoy the freedom to conduct, accept, or reject such research. "Thus, the field of researches must be wide open irrespective of the consequences because they are for the benefit of the human being," said Fletcher as quoted by El-Gendi (Jundi 1997b, 251). Besides Fletcher, El-Gendi mentioned Helen Spurway (19171978), professor at London University, and J. B. S. Haldane (1892-1964) (on him, see Clark 1968), introduced as one of the most brilliant scientists in the twentieth century, who proposed cloning people with unique characteristics such as a high pain threshold or the ability to see in darkness. ElGendi listed the top ten benefits of cloning as promoted by its advocates. Most of them are health-related issues such as improving the species of humankind, preventing hereditary diseases, giving children to infertile parents, controlling the sex of to-be-born children, and changing the physiological functions of some sorts of bacteria. El-Gendi also mentioned the possibility of producing a group of identical persons to be entrusted with special tasks during wars and finally surpassing the Russians and the Chinese in scientific research (Jundi 1997b, 250-53).

Hathout, in his Casablanca conference paper, focused on research by Jerry Hall and Robert Stillman from George Washington University on what he called "the new cloning: twinning." The two scientists, Hathout added, were awarded a scientific prize from the American Fertility Society for their research. However, they did not escape the firestorm of contro- 
versy triggered by their research. It began with a New York Times article, "Scientists Clone Human Embryos," written by G. Kolata (1993; on this incident, see Glausiusz 1999, 28-30). French president François Mitterrand condemned the research as horrifying, and similar stands were adopted by the Japanese Medical Society and the German scientific institutes. A response from the Vatican argued that such practices would push humankind into a channel of madness. In turn, the two scientists criticized the unrealistic sphere created by the media that focused on fantasies and groundless hypotheses rather than on the experiment itself and its scientific advantages. The scientists were counterattacked with further arguments elaborating the adverse effects of their research. According to some critics, artificial twinning would necessitate having leftover embryos that would either die or get implanted in other women's wombs. Both possibilities unavoidably cause ethical dilemmas. Additionally, this technology would not only create a "stock market for embryos" but also enable the purchaser to identify her forthcoming baby by checking his elder twin, already born. Through this technology, some embryos would be used as reserve in order to replace a dead child with an identical one or to get an organ or tissue that could be implanted in the twin already born. Is it ethically acceptable to originate life just for the sake of saving another life? The final argument advanced by the critics was named by Hathout "the far-sighted philosophical perspective," which, Hathout elaborated, opined that the continuity of life on Earth is largely dependent on embryonic diversity whereas opening the door for cloning would go contrary to this diversity (Hathūt 1997a, 8288).

In his Casablanca paper, Alfi dedicated a separate section to the different positions adopted by Western governments regarding Dolly. He classified them into three categories: proponents, opponents, and those who remain hesitant and skeptic. The proponents, composed mostly of endocrinologists (infertility specialists), advocated conducting research on human cloning and opined that the benefits of such research outweigh its harms. Opponents stood against conducting any research in this field, perceiving it as degrading the dignity of human beings and familial relations. They expressed fear about the probable misuse of this technology for nurturing racism and tyranny. This position, Alfi added, was already adopted officially by Western governments such as those of France, Germany, and England. The third group, mainly represented by the United States, preferred a waiting period before adopting any stand for or against cloning. They opted for an interim period during which research would be halted until the social and ethical dimensions could be duly investigated (Alfi 1997, 121-22).

The Muslim scientists thus gave a more or less comprehensive survey of the pros and cons concerning human cloning circulated in the Western intellectual milieus from the early 1970s, when different scholars discussed 
cloning in its own right and as a branch of the radical genetic possibilities, up to the most recent positions adopted by Western governments in the wake of cloning Dolly. Generally speaking, the role of the West was very clear throughout the proceedings of the two conferences. In his foreword to the published book of papers submitted to the Casablanca conference, El-Gendi wrote that choosing Morocco as the place to host the proceedings of this conference was aptly done. "Few miles away from here, there is Europe from which the issue of cloning originated and also the accompanying intense havoc in the media worldwide. That is why the Islamic Organization of Medical Sciences hastened to summon this symposium in the Maghreb in order to show the Islamic viewpoint in this serious issue" ('Awadì and al-Jundì 1997, 12).

\section{RELIGIOUS SCHOLARS: OPPONENTS AND PROPONENTS}

During the Casablanca conference, a paper written by Hasan al-Shāfi ì discussed aspects of cloning with relevance to Islamic theology. Four other papers, focusing on those aspects relevant to Islamic jurisprudence, were written by Hasan 'Alì al-Shādhilì, Muhammad Sulaymān al-Ashqar, Muhammad Mukhtār al-Salāmì, and Naş Farìd Wāsil. The papers of alShādhilì and al-Salāmì were read again during the Jeddah conference along with a third paper written by al-Taskhirì.

Al-Shāfi ì (b. 1930) is professor of Islamic theology and philosophy in the Faculty of Dār al-'Ulūm, Cairo University, and member of the Academy of the Arabic Language in Cairo. In the 1990s, al-Shäfi i served as rector of the Islamic University in Pakistan (on him, see Idrìisi 2008). AlShādhili (b. 1924), an Egyptian scholar, works as an expert in the Encyclopedia of Islamic Jurisprudence, the sector of issuing fatwas and religious researches affiliated with the Ministry of Religious Endowments (Awq $\bar{a} f)$ in Kuwait. Al-Ashqar is a Jordanian scholar specializing in the principles of Islamic jurisprudence and worked also as an expert in the Encyclopedia of Islamic Jurisprudence. Both al-Salāmi and Nasr Farìd Wāsil functioned as the state Mufti of Tunis and Egypt respectively. Finally, al-Taskhisi is head of the Culture and Islamic Relations League in Iran. All of these scholars, with the exception of Nass Farid Wassil, are affiliated with the IIFA as either members or experts.

Religious Scholars Esteeming Scientists. The religious scholars who participated in these conferences clearly paid tribute to the contributions of the scientists. Saudi scholar and IIFA member 'Abd al-Wahhāb Abū Sulaymān said that many of the religious scholars did not listen to scientists on this issue prior to the two conferences; they had no more than impressions and references in the newspapers and other media (Majallat $1997,406)$. The religious scholars' papers were largely based on the ones 
written by the scientists. For example, al-Salāmì said that the three valuable papers written by Hathout and El-Gendi were of benefit to him while writing on the issue $(1997,142)$. Quotations from the scientists' papers were visible in the religious scholars' papers especially concerning the scientific aspects of cloning and its eventual benefits or harms. Some scholars telephoned the scientists and asked for further clarifications on some points, as was the case with al-Shādhilì who contacted El-Gendi (al-Shādhilï 1997, 209).

In addition to admiring the scientists, all of the religious scholars who participated were unanimous in respecting and appreciating the value of science in general as one of the main principles in Islam. In support of this, references were made to verses in the Qur'ann purporting the value of science (51:20-23, 80:24-32, 88:17-22) (al-Shādhili 1997, 169-74; Wāsil 1997, 415-18; al-Taskhirì 1997, 219, 229; Majallat 1997, 370, 371, 374, 381). However, this appreciation for the value of science was not unlimited. Under the subtitle "Warning of the harmful science," al-Shādhili said that the main sources of Islam, the Qur'ān and the Sunna, condemn accumulating knowledge for the sake of harming oneself or others (al-Shādhili 1997, 175). However, the Syrian scholar and member of the European Council for Fatwa and Research 'Abd al-Sattār Abū Ghudda said that Islam distinguished between "learning" the harmful sciences and "practicing" them. To him only practicing is forbidden. Thus, he concluded, there is no harm in having a thorough knowledge of these scientific discoveries ('Awadì and al-Jundì 1997, 475).

Discussions of the religious scholars specifically about cloning divided them into two unequal groups, the majority as opponents and the minority, mainly represented by Sunnì scholar 'Abd Allāh Muhammad 'Abd Allāh and Shìì scholar al-Taskhìrì, as proponents. The discussions were based on two main considerations-those with relevance to Islamic theology and those relevant to Islamic jurisprudence.

Theological Considerations. A basic tenet of Islamic belief is that God is the sole creator of the universe, including human beings and all other creatures. Would cloning challenge this belief? Hasan al-Shāfi ì investigated this question in detail. He said that the term creation (khalq) has linguistic as well as theological connotations. Linguistically speaking, khalq has two main denotations. First, it means measuring or determining the proportion of something and then acting accordingly. Second, it means giving a form or shape to a substance already created by God. Creation in either meaning, al-Shāfi ì argued, can be attributed to God or to creatures. Theologically speaking, creation means bringing something into existence from the state of nonexistence without any external help. The second theological meaning is breathing life and soul into creatures. In these two theological meanings, creation is exclusive to God. 
After quoting Qur'anic verses and prophetic traditions in support of the fact that God is the only Creator in the theological sense of the term, alShafi i i concluded that the cloning of Dolly cannot be categorized under either of the two theological meanings of creation. The researchers did not breathe life or soul into Dolly but rather made good use of the laws of life and new technologies (al-Shāfi ì 1997, 215-17; see also Ashqar 1997, 32730). On his side, al-Satāmì referred to the Qur'anic verse "Or do they assign to Allah partners who have created [anything] as He has created, so that the creation seemed to them similar? Say: '[Allah] is the Creator of all things: He is the One, the Supreme and Irresistible" (13:16). Al-Satāmi not only answered the question in the negative but also scorned those who might think otherwise. These scientists did nothing more than study the laws of the divine creation carefully and then put them into practice. They did not create a cell, a nucleus, or a chromosome (al-Salāmì 1997, 14344). The religious scholars who participated in the discussions during the conferences came to the same conclusion (Majallat 1997, 365-66, 369; 'Awadì and al-Jundì 1997, 353).

Although cloning does not constitute a challenge to the belief that God is sole Creator, different theological objections were expressed especially concerning human cloning. One of these is that God elevated the human being to the highest rank among creatures, and human cloning would contradict this dignity conferred by God. Elaborating on the dignity of humans and its status in the universe was the subject of al-Shāfi îs paper at the Casablanca conference. He traced eight points in the Qur'ān and the Sunna, all testifying to human dignity in Islam. God created the human by God's own Hands and breathed into him from God's sprit, according to the Qur'anic verse "When I have fashioned him (in due proportion) and breathed into him of My spirit, fall ye down in obeisance unto him" (15:29). Al-Shâfi $i \mathrm{i}$ added that the human was exclusively designated by God to receive knowledge not accessible to the angels, as the Qur'ann says, "And He taught Adam the names of all things; then He placed them before the angels, and said: 'Tell me the names of these if ye are right.' They said: 'Glory to Thee, of knowledge We have none, save what Thou Hast taught us: In truth it is Thou Who art perfect in knowledge and wisdom” (02:3132). The human, different from God's other creatures, was selected as vicegerent, entrusted with populating Earth and taking care of it. Basing their contention on such arguments, the majority of the Muslim theologians opined that human beings are in principle elevated above the angels (al-Shāfìi 1997, 206-10; see Wāsil 1997, 423-24; al-Salāmì 1997, 155). Subjecting the human being to risky experiments that may result in defamed forms, the religious scholars argued, is sheer infringement on human dignity (Wâsil 1997, 423). In reference to artificial twinning, the scholars objected also to producing embryonic twins as reserve for an already born individual either to replace him/her in case of death or as an eventual source of organs or tissues if needed (al-Salāmì 1997, 155). 
Another theological objection was that human cloning is contrary to the normal course of human reproduction as known since the dawn of humanity. Under the subtitle "The manner of God the Almighty in creating man" Wāsil said that the unique way in which God created human beings is elaborated in detail in the Qur'ān, and he referenced fourteen examples (38:71-72, 04:01, 86:5-8, 12:30, 24:45, 32:7-9, 25:54, 07:11, 40:64, 64:03, 03:06, 59:24, 23:12-14, 53:45-46). An important element of this unique way of creation is being born as a result of a legal marriage between man and woman. One who comes to life in this way, argued Wạsil, is eligible to be the vicegerent of God on Earth (Wâsil 1997, 423-24; see al-Salāmi 1997, 149-51). Additionally, this "normal course of human reproduction" guarantees the male/female balance in life. The Kuwaiti scholar and member of the IIFA 'Ajul al-Nashmi said that this way of procreation produced a stable male/female balance with a percentage ranging between 52 and 48 since God created this universe and up to the present day. Opening the way to human cloning may jeopardize this balance ('Awadì and al-Jundì 1997, 478; al-Salāmì 1997, 157; Majallat 1997, 370-71).

The last theological consideration was "tampering with God's creation." Whether cloning is tantamount to this was a point of disagreement among religious scholars. The Syrian scholar and member of the IIFA Wahba alZuhayli argued that cloning is nothing but tampering with things. He referred to the Qur'anic verse "And among His Signs is the creation of the heavens and the earth, and the variations in your languages and your colours: verily in that are Signs for those who know" (30:22). Al-Zuhayli commented that the secret of life is to recognize beauty beside ugliness, the white and the black, the tall and the short. To him, cloning endangers a big issue in creation, namely, diversity. Making identical copies of beings thus is a danger for humanity itself (Majallat 1997, 371; see al-Shādhilï 1997, 202-3). He recalled two Qur'anic verses. The first tells about the plans of Satan to deceive humans: "And surely I [the Satan] will command them and they will cut the cattle's ears, and surely I will command them and they will change Allah's creation" (04:119). The second states, "Then set your face upright for religion in the right state, the nature made by Allah in which He has made men; there is no altering of Allah's creation" (30:30). On the basis of these verses, Muslim scholars stated that any temptation to change God's creation is a demonic one and thus strictly forbidden in Islam. Al-Ashqar said that as long as cloning does not produce a hen with six legs or two heads or a cow with three eyes, cloning does not fall under the forbidden "alteration of God's creation" (1997, 322-23). Although alAshqar's conclusion was supported by Muhammad al-Khayyạt, it was countered by strong objections, such as those from the Moroccan professor of Islamic studies Muhammad al-Kharshāfî and the Saudi scholar 'Abd Allāh Ibn Manì' ('Awadì and al-Jundì 1997, 366, 374; Wāsil 1997, 429; Majallat 1997, 390-91). 
Juristic Considerations. Religious scholars participating in these conferences distinguished between cloning animals and plants and cloning humans. As for cloning animals and plants, there was almost complete agreement that it is allowed in Islam. The main argument was that God created all living beings in this universe to be in the service of human beings. Al-Shādhili spoke about the concept of taskhìr and said that it is elaborated in eighteen Qur'anic verses. Taskhìr, as outlined by these verses, means that the heavens and the earth with all they contain have been subjugated by God to be in the service of humans, as a gift from God. Humanity is entrusted to use this gift as long as such use does not entail breaching any of the divine prescriptions. Because using the technology of cloning in plants and animals would benefit humans, there is no harm in doing so. Some scholars said that such cloning is not only permissible in Islam but even required, and researchers should be encouraged to master the technology (al-Shādhilì 1997, 178-80; see al-Salāmì 1997, 143; Wāsil 1997, 418-20). However, other voices in the two conferences stressed that cloning plants and animals should not be without restrictions. Al-Satāmi said that cloned products should not be made available for human consumption before it becomes certain that they do not expose humans to any harm. Additionally, he argued, cloning new breeds should not lead to the extinction of the old breeds because the new breeds might produce new microbes in the long run (al-Salāmì 1997).

Discussions on the cloning of humans were much more lengthy, complex, and controversial. Clearly the religious scholars were influenced by the potential benefits and harms of cloning as outlined by the scientists. The scholars opined that the possible harms clearly outweighed the benefits, and Western scientists such as Watson were quoted again by the religious scholars to support this conclusion (Ashqar 1997, 335-42; Wāsil 1997, 430-42, 454). The information the scientists presented about what exactly each type of cloning meant was also an important guideline for the religious scholars. The starting point of the discussions below is that any cloning involving unmarried couples is forbidden. The scholars agreed that the only permissible way for procreation in Islam is the legal marriage between man and woman.

Concerning what the religious scholars called traditional (reproductive) cloning, the overwhelming majority agreed that it is forbidden in Islam. The different stages of a baby born to married couples are detailed in the Qur'ān. Al-Shädhili quoted these verses: "So let man see from what he is created! He is created from a water gushing forth. Proceeding from between the back-bone and the ribs" (86:5-7). He considered this passage to be a clear statement that the human being is composed of both the man's sperm (back-bone) and the woman's egg (ribs). Thus, parenthood is based not only on a legally valid marriage contract between the spouses but also on the biological collaboration between them. This collaboration, explained 
al-Shādhilì, is missing in the case of reproductive cloning, which consists of transferring the nucleus of an adult cell containing 46 chromosomes to an egg whose nucleus, and thus its genetic material, has been removed. The egg, genetically speaking, has no role in this procreation and thus there is no motherhood in the religious sense (al-Shādhili 1997, 187-92). Wâsil added that although there is no mixture of lineages if the process involves a married couple, the relation between the wife and the baby will not be normal. The woman will not feel that this baby, who does not carry any of her genetic traits, is her own child (Wâsil 1997, 445). There are problems with establishing the fatherhood as well, even if the cell is taken from the husband. Al-Ashqar said that this cell, taken from the husband, was originally fertilized by his father's sperm, not by the husband's. Because the embryo has not been fertilized by his own sperm he cannot be recognized, in the religious sense, as the father.

The scholars concluded that it is almost impossible to establish the degree of the relationship between such a baby and the couple, not to mention the other relatives. This makes the application of other religious rulings based on defining the degree of the relationship also impossible, such as inheritance, familial rights and obligations, and marriage possibilities (alAshqar 1997, 345-46; al-Shādhilì 1997, 184-87, 192-93).

Is it permissible to use reproductive cloning as the sole medical treatment for infertility between married couples? This question was answered in the negative, and the scholars used more than one argument.

Al-Shädhili said that global population is increasing to the extent that many countries suffer from overpopulation. Thus, infertility remains an individual issue, not a global one. Treating individual cases according to Islamic law, al-Shädhili explained, should not be at the cost of the public interest. Reproductive cloning may help married couples who are craving a child but could harm the larger society. Additionally, reproductive cloning would not give these couples the child they desire, al-Shādhili concluded (1997, 195-98). Wâsil spoke about the wise purposes (bikam) of infertility intended by God that would be halted by using reproductive cloning as a medical treatment. Infertile couples, Wâsil elaborated, are the ones who mostly take care of orphans and foundlings because they long for children. Who will take care of these children if there are no infertile couples? (Wāsil 1997, 445-46)

The religious scholars also discussed artificial twinning. Muhammad alAshqar opined that, concerning its ruling in Islamic law, this procedure is close to the technique of in vitro fertilization (IVF), already approved by the Muslim scholars. Through IVF, the woman's egg gets fertilized by the man's sperm outside the womb and then inserted into the woman's womb. This technique may result in twin test-tube babies. Al-Ashqar argued that this is more or less the case with the artificial twinning; the embryo that gets split into two cells is originally the woman's egg fertilized by the man's 
sperm. The only difference is that test-tube twins would be conceived in one pregnancy whereas with artificial twinning there could be more than one pregnancy. Thus, al-Ashqar concluded, artificial twinning is permissible in Islam if the same conditions required for IVF are fulfilled-the process involves a married couple, during their marriage, with the consent of both, and leftover embryos must be destroyed if the marriage ends or one of them dies (Ashqar 1997, 343-44).

$\mathrm{Al}-\mathrm{Sh} \overline{\mathrm{a}} \mathrm{dhili}$ disagreed. In his opinion artificial twinning cannot be equated with IVF. The substantial difference is that test-tube twins are two independent children, each of whom has an independent egg fertilized by an independent sperm and thus enjoys an independent identity with unique characteristics. In artificial twinning, there is only one original embryo out of which identical copies are made, all of which are nothing more than one identity with identical genetic traits. Having multiples of one personwho might have different bodies and ages but identical characteristicswould create legal problems. How can we, in such cases of identical people, identify those entrusted with rights and those with obligations in Islam? al-Shādhili wondered. Who will be punished if one of these identical persons commits a crime without being specified? (1997, 207-8). Basing his information on Hathout's paper, al-Shādhilì spoke also of possible misuses of this technology. For instance, the frozen leftover cloned embryos can be used as reserve in order to replace a dead child or to obtain an organ or tissue for implanting in the already living child. To him, this is forbidden in Islam because the human life must be protected even if it was in the embryonic stage (1997, 202-3).

The last type of cloning that the religious scholars discussed was therapeutic cloning. In their presentations, the scientists pointed out that cloning organs rather than a whole body is, scientifically speaking, impractical. They added that this type of cloning proved to be successful only in skin tissues. Hence, this type was discussed just in passing by al-Shādhilì. He stated that if the scientists managed to clone specific organs or tissues instead of cloning a whole body, it is in principle allowed and even required in Islam to make use of these organs as a medical treatment (al-Shädhili 1997, 212-13).

Arguments of the Proponents. Despite the dominance of those opposed to cloning, especially reproductive cloning, there were pro-cloning advocates at both conferences. Representing the pro-cloning trend in the Casablanca conference was Kuwaiti scholar 'Abd Allāh Muhammad 'Abd Allāh, who served as a judge in the Kuwaiti Supreme Court. He did not submit a paper but expressed his opinion during the discussions. He spoke about the controversial reproductive cloning. To him, using this as a medical treatment for infertility in legally married couples should not be problematic in Islamic law, especially because procreation is one of the main 
objectives of marriage in Islam. He referred to the scientists, who unanimously agreed that a child born through reproductive cloning would have 97 percent of the father's genetic characteristics. Hence, such a child would be produced by a husband and a wife during a legally valid marriage and after the full period of pregnancy. How can we say to such couples that this child is not yours? 'Abd Allāh wondered. He argued that such an opinion would be rigorism (tashaddud). Finally, to overcome the negative connotations of the term "cloning" for some of the religious scholars, 'Abd Allāh suggested using another expression such as "treating infertility between married couples." Al-Salāmì heavily criticized this suggestion, saying, "May God forgive him! Are we so naïve that changing the name will make us change our perspective towards things?" At the end, it was clear that the opinion of 'Abd Allāh did not appeal to the participants ('Awadì and alJundì 1997, 470, 490).

At the Jeddah conference, the main advocate of human cloning in general was Iranian scholar Muhammad 'Alì al-Taskhirì, who presented a paper. He began with an overview of the two main types of cloning, "traditional" reproductive and the "new" artificial twinning. This division disappeared in the rest of the paper, a fact that implied that al-Taskhiri was advocating both types of cloning (al-Taskhiri 1997, 217-18). Initially, alTaskhirì contended that current emotional discussions of cloning, replete with terrific and fearful fantasies, make it all but impossible for the researcher to retain the required objectivity. The researcher would easily be subconsciously inclined to join either the pro- or the anti-cloning side. As for the religious scholars, al-Taskhiri argued, joining those opposed to cloning is more probable, because they want to block any potential way to the postulated evils of cloning as described by the anti-cloning group and thus conclude that cloning is absolutely forbidden in Islam.

After reviewing the long list of possible benefits and harms as outlined by the scientists, al-Taskhiri dedicated the rest of his paper to refuting the postulated evils and, as he said, stepping away from the emotional sphere that predominated in the discussions (1997, 218-22). Regarding potential harms to the family institution, he allowed that cloning would produce children whose parents, within the pertinent juristic rulings in Islam, cannot be established with certainty. He responded that the application of cloning would remain restricted to individual cases and would not become a widespread phenomenon. Keeping this in mind, he argued, there would be no overwhelming harm in having individual cases where the child's parenthood or fatherhood cannot be established. Another possible harm was that cloning would put an end to the phenomenon of marriage as a means to procreate. In response, al-Taskhïrì said that gaining children through cloning would not be the end of marriage because people do not get married exclusively to get children. In reference to artificial twinning, al-Taskhirì responded to the protest that the younger twin would be able 
to predict his or her diseases through the life of the elder. He said that such foreknowledge has positive effects as well because it should motivate the younger to seek protection from such diseases before they began attacking him or her.

What of the postulated evils of cloning against societies at large? The claim that cloning would deprive the human being of its humanness, alTaskhiri argued, is not supported by evidence. On the contrary, cloning could be a means of saving some societies or families from their genetic diseases. Concerning the threat to embryonic diversity, al-Taskhîrì said that there is yet no evidence that cloning would produce 100 percent identical copies. Also, differing environments and external factors would surely result in a certain degree of difference among the copies.

The difficulty of defining the relationship between the cloned baby and the donor of the cell and other family members did not escape the attention of al-Taskhiri. He conceded that this would create complications within Islamic jurisprudence. However, such complications should motivate the religious scholars to find possible solutions rather than closing the door from the very beginning and depriving humanity of the marvelous results of these researches. Finally, what about the untold number of possible misuses of this new technology? The same complaint, said al-Taskhirit, is applicable to the IVF technique already approved by the Muslim scholars (1997, 222-26).

The conference participants seemed to be impressed by al-Taskhirì's presentation. Ibn Manì spoke about its "magical eloquence." In a humorous reference to his fear that this eloquence would affect the other participants, he said, "I ask God to protect us from his magic!" (Majallat 1997, 390).

Final Standpoints. As already mentioned, an important characteristic of the collective interpretation (ijtihad jam $\bar{a} \vec{\imath}$ ) is that it begins with diversity and ends with unification. This was exactly the case with the discussions of the IOMS and the IIFA on cloning.

Specific members were selected to draft the final recommendations and resolutions. For the Casablanca conference, the drafting committee consisted of six members: two scientists (Alfi and Hathout), three religious scholars (al-Ashqar, al-Shādhilì, and Wāsil), and a lawyer (Mustafāa alRumayd) ('Awadì and al-Jundì 1997, 498). The final declaration was clear that all cases of cloning beyond legally married couples are forbidden. Concerning the different types of cloning, the final declaration was permissive but hesitant toward artificial twinning. Although the final declaration stated that there are no objections in principle to this method of fertilization, it deemed it too early to evaluate its advantages and disadvantages. If this technique were to be used in procreation, the juristic rulings pertinent to the IVF technique would apply. As for reproductive cloning, 
the declaration stated, this technique implies a number of grievous dangers for both the uniqueness of the human identity and the social structure of families, relationships, and societies as known throughout human history. Thus, this type of cloning is forbidden, but if exceptional cases appear in the future, they should be subject to further investigation of the pertinent juristic rulings in Islam.

The declaration stated that there is no harm in using cloning and genetic engineering techniques in the botanical and zoological fields as long as such use remains compliant with well-known ethical considerations. Notably, it made no reference to therapeutic cloning, probably because of its impracticality as expressed by the scientists. Beyond the religious aspects, the declaration lamented the current situation of the Islamic world concerning the modern sciences and called for establishing institutes that would conduct scientific research pursuant to the religious regulations. Finally, the declaration requested that Islamic countries enact laws prohibiting foreign institutions and researchers from using the soil of Islamic countries as a field for experiments on cloning ('Awadì and al-Jundì 1997, 508-13). A special session was dedicated to discussing all the points raised in the final declaration, but no objections were raised by participants against any of the points. Most of the remarks had to do with stylistic and linguistic changes ('Awadì and al-Jundì 1997, 519-29).

At the Jeddah conference, discussions around the final declaration were much more complicated. Because of the religious character of the IIFA, the final declaration would take the form of a fatwa rather than a declaration. Thus, many of the conference participants preferred to postpone a final decision about the juristic rulings on cloning because the topic is still immature (Majallat 1997, 368, 373, 374, 387, 404, 407). Others reasoned that a clear stand should be taken concerning cloning, a serious issue for people throughout the world. The main argument of this group was that reputable international institutions such as the Vatican and countries such as the United States had already adopted positions. They wondered why this fiqh academy, which represents the majority of Muslims worldwide, should have no clear standpoint (Majallat 1997, 370, 372, 392).

In the end, the second group proved to be more influential, and a final resolution was adopted by the IIFA recorded under the number 100/2/10. The drafting committee consisted of four religious scholars ('Abd Allāh ben Bayya, 'Abd Allāh b. Mañì', 'Alì al-Salūs, and Nażih Hammād) and three scientists (Sālih Kurayyim, Muhammad 'Alì al-Bār, and Muhammad Haytham al-Khayyạt) (Majallat 1997, 414). The resolution began by stating that all papers submitted to and the recommendations issued by the Casablanca conference were taken into consideration. Thus, different points were adopted from the final declaration of the Casablanca conference such as prohibiting any type of cloning involving unmarried couples, the permissibility of cloning in the botanical and zoological fields, and calling for 
establishing Sharía-compliant scientific institutions in the Muslim world. Contrary to the final declaration of the Casablanca conference, which was permissive toward artificial twinning, the resolution of this conference declared that both types of human cloning, reproductive and twinning, and any other type that might lead to human procreation, are categorically forbidden (Majallat 1997, 417-23).

\section{FURTHER DEVELOPMENTS: MUSLIMS IN THE WeST}

Concerning ethical discussions on cloning in the West, Callahan has argued that the discussions of the 1970s are representative and that no new arguments have since been advanced (Callahan 2001, 105). If this statement can apply to specific discussions in the Muslim world, it should be those that took place during these conferences in 1997. However, although most of the cogent arguments in Western discourse may have developed in the 1970s, new situations have arisen that have required fresh analysis by Islamic authorities. One comprehensive study that reviews the opinions of Muslim scholars on cloning is the two-volume Al-Mawsī'a al-fiqhiyya li al-ajinna wa al-istinsākh al-basharit (Juristic Encyclopedia on Embryos and Human Cloning), prepared by Sa ìd b. Mansūr Mūfa'a, the Faculty of Sharì'a and Law, San '⿳亠口了' University in Yemen. Perusing such a study and similar ones reveals how representative and influential the discussions and the final declarations of these conferences have been on subsequent discussions in the Muslim world (Mūfa'a 2005). As an example we refer to the IFA, which represents the third side of the triangle of institutions, together with IOMS and IIFA, with major contributions in Islamic bioethics. About one year after the Casablanca and Jeddah conferences, the IFA discussed cloning in its fifteenth session held in Mecca 4 November 1998 and confirmed the resolution adopted by the IIFA (Al-Qarār al-Awwal 1999, 157).

The point is that the influence of the ethical discussions in and the positions adopted by the conferences organized by these international religioscientific institutions extends also to Muslims living in the West. The IOMS was aware from the beginning of these Muslim communities living outside the Muslim world. In a 1983 seminar, 'Abd al-Rahmān al'Awadì, president of IOMS, said that a main aim of the seminar was "meeting our responsibilities, as Muslims living in Muslim Arab countries, towards the ever-growing Muslim communities in the Western world, by offering them the Islamic viewpoint (as much as we are enabled by God to do so), because they have to face these developments which are taking place around them" (Gindi 1989, 10). The same idea was repeated during the Casablanca conference ('Awadì and al-Jundì 1997, 13, 69). To show the overseas influence of IOMS I mention Muzaffar Iqbāl, founding president of the Center for Islam and Science in Canada, who discussed the position of Islam toward different bioethical issues and then said, "A representative example 
of Muslim opinions on these issues can be found in the proceedings of a series of conferences organized by the Islamic Organization for Medical Sciences" (Iqbāl 2007, 187). In his book Radical Reform, Tariq Ramadan, a Muslim intellectual in the West, includes a chapter on Islamic ethics and medical sciences. He refers frequently to the IOMS, its Web site, activities, and publications such as its series Islamic Visions on Some Medical Practices. Ramadan commends the work method of IOMS that combines religious scholars and scientists (Ramadan 2009, 165, 364, 366).

The importance of the IOMS is gradually being recognized by the nonMuslim Western scientific and intellectual elite as well. A recent article by Dutch gynecologist Dr. J. Lind bears witness to this. Lind writes about the IOMS and the annual conferences they organize, "This organization seems to be the most prominent in this field and the codes they set up for behavior, research and ethics enjoy respect in the Muslim world. Islamic academics from the whole world participate in this and the conclusions of these conferences can serve as a guide for the imams" (Lind 2008, 1720).

Focusing on cloning in particular, a main channel through which the ethical standpoints adopted by IOMS and IIFA reach Muslims in the West is the European Council for Fatwa and Research (ECFR). This council, established in 1997 and based in Dublin, Ireland, focuses on issues with specific relevance to Muslim minorities in the West (http://www.e-cfr.org/ en/). Fatwas issued by this council enjoy growing acceptance among Muslims living in Europe in addition to interest among political authorities (Koningsveld 2006, 208-21). A parallel channel especially for Muslims living in the United States is the Assembly of Muslim Jurists in America (AMJA), established in 2002 ( $h t t p: / / w w w$.amjaonline.com/index.php).

ECFR president Yūsuf al-Qarad̄âtì has stressed that the relation between ECFR and other juristic academies in the Muslim world such as IIFA and IFA are complementary rather than competitive: "The ECFR will surely benefit from the resolutions adopted by and the researches submitted to these reputable academies" (Majlis 2002, 7). This proposed collaboration was crystal clear in the case of cloning. For instance, the members of ECFR were involved in the proceedings of the Casablanca and Jeddah conferences. Different members attended and participated in the discussions there. 'Abd al-Sattār Abū Ghudda and Muhammad al-Hawwārì attended the Casablanca conference ('Awadì and al-Jundì 1997, 545, 547). 'Abd Allāh ben Bayya attended the Jeddah conference and was a member of the drafting committee (Majallat 1997, 365, 414). Additionally, Abū Ghudda and al-Hawwāì submitted papers on cloning when the ECFR discussed this issue in its tenth session 22-26 January 2003 in Dublin. The paper of al-Hawwāì focused on the scientific sides of cloning. He quoted the entire paper of Hathout on "Cloning and the Hypothesizers" presented to the Casablanca conference. Al-Hawwāri appended to his paper the final declaration of the Casablanca conference and the resolution 
of the IIFA (al-Hawwārì 2003, 209-54.). Abū Ghudda focused on the theological and juristic aspects of cloning, referring extensively to the contributions of the religious scholars during both conferences (Abu Ghudda 2003).

The fatwa of the ECFR on cloning, no. $1 / 10$, began by stating that the ECFR adopts the resolution of the IIFA no. $942 / 10$. The full text of this resolution was quoted. Additionally, the fatwa of the ECFR filled in two important gaps in the final declaration of the Casablanca conference and in the resolution of the IIFA about therapeutic cloning and cloning in the fields of plants and animals. On therapeutic cloning, the ECFR opined that it is permissible to use stem cells to produce healthy organs that can replace defective ones provided that this does not lead to damaging a fetus older than 40 days. As for cloning animals and plants, the ECFR wanted to paraphrase the position adopted by the IIFA and IOMS that this type of cloning is permissible as long as it remains compliant with well-known ethical considerations. The council named three main considerations: that there should be a benefit recognized by the Sharía, that this benefit should not clash with a greater harm, and that this technology should not lead to torturing the animal or to changing its creation (Al-Qarār 2003, 353-58).

I conclude this section with a reference to a fatwa issued by AMJA on cloning. The AMJA received the question, "What is the Sharí' a ruling on cloning? Please, kindly counsel me in details with evidence, if possible." The fatwa, dated 07-02-2005 and issued by Salāh al-Sāwì, the AMJA secretary general, was published on the AMJA Web site. It referred the questioner to the aforementioned resolution of IIFA, followed by the full text of the resolution (http://www.amjaonline.com/en_f_details.php? $f i d=553$ ).

\section{CONCLUSIONS}

This article has reviewed the main discussions in the Muslim world on cloning in the wake of the February 1997 announcement that Dolly the sheep had been cloned. These discussions took place during two largescale international conferences.

The discussions showed that Muslim religious scholars realize that serious bioethical issues cannot be approached solely by religious scholars, much less by an individual. Thus, biomedical scientists played a crucial role in these discussions. The scientists enjoyed the trust and the admiration of the religious scholars. This collaboration between the religious scholars and the scientists falls within what is known in the Islamic tradition as the collective interpretation (ijtihäd jama $\vec{a}$ ). Future academic studies on Islamic bioethics should pay attention to this type of ijtihäd and especially to the role of these scientists and their influence in this process.

In the midst of the untold number of fatwas and ethical standpoints of modern individual Muslim religious scholars, the bioethical positions adopted by the Islamic international religioscientific institutions such as 
IOMS and IIFA remain the most representative and most influential. This is mainly because of the collective interpretation practiced within these institutions where authoritative religious scholars from different Muslim countries, trends, and ethnic backgrounds work together with prominent Muslim scientists.

The influence of these institutions is not restricted to Muslims living in the Muslim world but extends to Muslims living as religious minorities in the West and also to the intellectual and scientific elite in the West. This link between Muslim countries-based institutions and Muslims in the West is realized through different channels. We mentioned two of these channels: the European Council for Fatwa and Research and the Assembly of Muslim Jurists in America.

The phenomenon of rapid globalization that dominates our era is reflected in Islamic bioethics where ideas frequently cross geographical borders from the West to the Muslim world and vice versa. The positions of Western bioethicists and scientists such as James D. Watson, Leon Kass, Daniel Callahan, Joseph Fletcher, and many others influence the bioethical discussions of the Islamic international institutions, and the standpoints adopted by these institutions find their way back to the West.

\section{NOTES}

A version of this article was read during the Venice Summer School on Science and Religion, 26-30 May 2009. I thank the organizers of the School for accepting the article and the participant scholars for their useful comments. Gratitude goes also to Prof. Muhammad 'Alì al-Bār (International Medical Center, Jeddah, Saudi Arabia), Prof. P. S. van Koningsveld, and Prof. W. B. Drees (both Leiden University) for their critical and useful remarks on earlier drafts.

1. I could not find further biographical information about him even on the Web site of the university, http://www.univ-ibntofail.ac.malfralindex.php. Additionally, I am not certain of the correct reading of his family name. In the IOMS publication, the name is written in two different ways, and each of them can be read in different ways. So it could be Yashyawì, Yüshyawì, Yashawì , Yashwài, Yūshwì, or another variation.

\section{REFERENCES}

'Awadìi, 'Abd al-Rahmān al-, and Ahmad al-Jundì. 1997. Ru'ya Islāmiyya li ba'd al-mushkilāt al-tibbiyya al-mu'ăsra (Islamic vision of some medical practices). Kuwait: Al-Munazzama al-Islāmiyya li al-'Ulūm al-Ṭibbiyya.

'Awad̦i, Șadīqa al-. 1997. "Al-Istinsākh (al-klūna)." In Ru'ya Ișlāmiyya li ba'd al-mushkilāt altibbiyya al-mu'ạsra, ed. 'Abd al-Rahmān al-'Awad̦ì and Ahmad al-Jundì, 161-73. Kuwait: Al-Munazzama al-Islāmiyya li al-'Ulūm al-Tibbiyya.

Abū Ghudda, 'Abd al-Sattār. 2003. Al-Istinsākh min al-zawjayn wa al-ahkām allatì tatarattab 'alā dhālik (Cloning from a married couple and the ensuing rulings). Paper submitted to the tenth session of the the European Council for Fatwa and Research. http://www.ecfrorglarl.

Al Fadhli, Suad, Abdulmutalib Behbehani, Alaa Elshafey, and Sidky Abdelmoaty. 2008. "Molecular and Clinical Evaluation of Primary Congenital Glaucoma in Kuwait." American Journal of Ophthalmology 141 (3): 512-16.

Alfi, 'Umar. 1997. "Al-Istinsākh al-basharì: Al-Jawānib al-ilmiyya li al-maudū' wa āfāquh" (Human cloning: Scientific dimensions and future perspectives). In Rúya Islāmiyya li ba'd al-mushkilät al-tibbiyya al-mu'ạsra, ed. 'Abd al-Rahmān al-'Awad̦i and Ahmad alJundì, 117-25. Kuwait: Al-Munazzama al-Islāmiyya li al-'Ulūm al-Ṭibbiyya. 
Alfi, Omar S., George N. Donnell, and Anna Derencsenyi. 1971. "Quinacrine fluoromicroscopy in the identification of human mitotic chromosomes." Pediatrics 48 (3): 423-25.

Ashqar, Muhammad al-. 1997. "Al-Istinsākh fi māzān al-sharì'a al-Islāmiyya" (Cloning within the perspective of the Islamic Sharí'a). In Ru'ya Isslāmiyya li ba'd al-mushkilāt al-tibbiyya al-mu'ạsra, ed. 'Abd al-Rahmān al-'Awadì and Ahmad al-Jundì, 316-49. Kuwait: AlMunazzama al-Islāmiyya li al-'Ulūm al-Țibbiyya.

Awadi, S. A. Al-, M. A. Moussa, K. K. Naghuib, and T. I. Farag. 1985. "Consanguinity among the Kuwaiti population." Clinical Genetics 27 (5): 483-86.

Awadi, S. A. Al-, K. K. Naguib, M. A. Moussa, and T. I. Farag. 1986. "The effect of consanguineous marriages on reproductive wastage." Clinical Genetics 29 (5): 384-88.

Banchoff, Thomas, ed. 2008. Religious Pluralism, Globalization, and World Politics. Oxford: Oxford Univ. Press.

Callahan, Daniel. 2001. "Cloning, Then and Now." In The Cloning Source Book, ed. Arlene Judith Klotzko, 104-8. Oxford: Oxford Univ. Press.

Clark, Ronald. 1968. J. B. S.: The Life and Work of J. B. S. Haldane. London: Hodder \& Stoughton.

Eich, Thomas. 2006. "The Debate on Human Cloning among Muslim Religious Scholars since 1997." In Cross-Cultural Issues in Bioethics: The Example of Cloning, ed. Heiner Roetz, 291-309. Amsterdam: Rodopi.

Frey, R. G., and Christopher Wellman, eds. 2003. A Companion to Applied Ethics. Malden, Mass.: Blackwell.

Giberson, Karl. 2008. Saving Darwin: How to Be a Christian and Believe in Evolution. New York: HarperCollins.

Gindi, Ahmad al-, ed. 1989. Human Reproduction in Islam. Kuwait: Islamic Organization of Medical Sciences.

Glausiusz, Josie. 1999. "Artificial Twinning Is Not Cloning." In Cloning: For and Against, ed. M. L. Rantala and Arthur J. Milgram, 28-30. Chicago: Open Court.

Hathūt, Hassān. 1997a. "Istinsākh al-bashar" (Cloning humans). In Ru'ya Islāmiyya li ba'd al-mushkilāt al-tibbiyya al-mu'ạsra, ed. 'Abd al-Rahmān al-'Awadì and Ahmad al-Jundì, 75-89. Kuwait: Al-Munazzama al-Istāmiyya li al-'Ulūm al-Tibbiyya.

. 1997b. "Al-Istinsākh wa 'al-ara'aytiyyūn'" (Cloning and the hypothesizers). In Ru'ya Istạmiyya li ba'd al-mushkilāt al-tibbiyya al-mu'ạsra, ed. 'Abd al-Rahmān al-'Awaḍi and Ahmad al-Jundì, 91-100. Kuwait: Al-Munazzama al-Islāmiyya li al-'Ulūm al-Ṭibbiyya.

Hawwā̄ì Muhammad. 2003. "Al-Istinsākh al-basharì bayn al-thawra al-'ilmiyya wa al-dawābit al-akhāliqiyya wa al-fiqhiyya" (Human cloning between the scientific revolution and the ethical and juristic criteria). Scientific Review of the European Council for Fatwa and Research 3:209-54.

Hayani, Fatima Agha al-. 2008. "Biomedical Ethics: Muslim Perspectives on Stem Cell Research and Cloning." Zygon: Journal of Religion and Science 43:783-95.

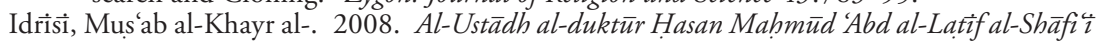
shaykhan (Prof. Dr. Hasan Mahmoud Abd al-Latif as-Shafi'i as Shaykh). http://www.aslein .net/showthread.php? $p=57505$.

Iqbāl, Muzaffar. 2007. Science and Islam. Westport: Greenwood.

Jenkins, Edmund C., W. Ted Brown, Miriam G. Wilson, and Ming S. Lin. 1985. "The prenatal detection of the fragile X chromosome: Review of recent experience." American Journal of Medical Genetics 23:1-2, 297-311.

Jundì, Ahmad al-. 1997a. "Al-Istinsākh al-basharì bayn al-iqdām wa al-ihjām" (Human cloning between boldness and refrainment). In Ru'ya Islāmiyya li ba'd al-mushkilāt al-tibbiyya al-mu'āsra, ed. 'Abd al-Rahmān al-'Awad̄ì and Ahmad al-Jundì, 127-55. Kuwait: AlMunazzama al-Istāmiyya li al-'Ulūm al-Ṭibbiyya.

. 1997b. "Al-Istinisākh al-basharì bayn al-iqdām wa al-ihjām." Majallat Majma' alFiqh al-Islāmì 10 (3): 235-69. Jeddah: International Islamic Fiqh Academy.

Kass, Leon, and James Wilson. 1998. The Ethics of Human Cloning. Washington, D.C.: American Enterprise Institute Press.

Kolata, G. 1993. "Scientists Clone Human Embryos, and Create an Ethical Challenge." New York Times (24 October), A1-A22.

Koningsveld, P. S. 2006. "The Significance of Fatwas for Muslims in Europe." Nederlands Theologisch Tijdschrift 60 (3): 208-21. 
Kurayyim, Sālih al-. 1997. "Al-istinsākh: taqniyya, fawā'id wa makhātir" (Cloning: technology, benefits and risks). Majallat Majma' al-Figh al-Islāmì 10 (3) 271-311. Jeddah: International Islamic Fiqh Academy.

Levey, Martin. 1967. "Medical ethics of medieval Islam with special reference to al-Ruhāwì's 'Practical ethics of the physician." Transactions of the American Philosophical Society 57 (3): $1-100$.

Lind, J. 2008. "Als de imam beslist" (When the imam decides). Medisch Contact 63:42 (17 October), 1719-22.

Majallat Majma' al-Fiqhì al-Islāmì. 1997. Jeddah: International Islamic Fiqh Academy 10 (3): $131-450$.

Majlis al-Urubbì li al-Iftā' wa al-Buhūth, al-. 2002. Qarārāt wa fatāw $\bar{a}$ (Resolutions and fatwas). Cairo: Dār al-Tawzî̀ wa al-Nashr al-Ișlāmiyya.

Mūfáa, Sạid. 2005. Al-Maws'̄'́a al-fiqhiyya li al-ajinna wa al-istinsākhh al-basharì (Juristic encyclopedia on embryos and human cloning). Alexandria: Dār al-Īmān.

Poland, Susan, and Laura Bishop. 2002. "Bioethics and Cloning, Part I." Kennedy Institute of Ethics Journal 12 (3): 305-24.

President's Council on Bioethics. 2002. "Human Cloning and Human Dignity: An Ethical Inquiry." www. bioethics.gov.

Qarad̄āwì̄, Ỵūsuf al-. 1994. Al-Ijtih̄ād al-mu'asir bayn al-indibāt wa al-infriāt. Cairo: Dār alNashr wa al-Tawż̈ al-Ișlāmiyya.

Qarār, al-. 2003. "Hukm al-istinsākh" (The religious ruling on cloning). Scientific Review of the European Council for Fatwa and Research 3:353-58.

Qarār al-Awwal, al-. 1999. "Istifādat al Muslimìn min 'ilm al-Handasa al-wirāthiyya" (Muslims benefiting from the genetic engineering). Majallat Majma' al-Fìq $\bar{\imath}$ al-Islāmmì 12:15758. Mecca: The Muslim World League.

Ramadan, Tariq. 2009. Radical Reform: Islamic Ethics and Liberation, Oxford: Oxford Univ. Press.

Roe, Thomas F., and Omar S. Alfi. 1977. "Ambiguous genitalia in XX male children: Report of two infants." Pediatrics 60:55-59.

Ruhāwi, Ishāq b. 'Alì al-. 1992. Adab al-tabìb. Murayzin Sa ìd Murayzin 'Așiri (ed.). al-Riyaydh: Markaz al-Malik Fayșal li al-Buhūt wa-al-Dịrāsāt al-Iștāmiyya.

Salāmì, Muhammad al-. 1997. "Al-Istinsākh." Majallat Majma' al-Fiqh al-Islāmì. Jeddah: International Islamic Fiqh Academy 10 (3): 137-61.

Shādhilì, Hasan al-. 1997. "Al-Istinsākh: Haqiquatuh, anwāùh, hukm kull naw' fi al-Fiqh alIslāmì." Majallat Majma" al-Fiqh al-Islāmì. Jeddah: International Islamic Fiqh Academy 10 (3): 165-213.

Shāfî̀, Hasan al-. 1997. "Karāmat al-insān wa makānatuh fi al-kawn." In Rủya Islāmiyya li ba'd al-mushkilāt al-tibbiyya al-mu'āsra, ed. 'Abd al-Rahmān al-'Awadì and Ạmad alJundì, 204-25. Kuwait: Al-Munazzama al-Istāmiyya li al-'Ulūm al-Tibbiyya.

Steinfels, Peter. 1991. "Dr. Joseph F. Fletcher, 86, Dies; Pioneer in Field of Medical Ethics." The New York Times (30 October), 25.

Taskhirì, Muhammad al-. 1997. Nazra fi al-istinsākh wa Hukmuh al-shar ì. Majallat Majma al-Fiqh al-Islāmì. Jeddah: International Islamic Fiqh Academy 10 (3): 217-34.

Twair, McDonnell. 2008. "Dr. Hassan Hathout: A Survivor of the 1948 Nakba and the Siege of Ramle." Washington Report on Middle East Affairs (May-June), 26-27.

Wāsil, Nasr. 1997. Al-Istinsākh al-basharì wa ahkāmuh al-tibbiyya wa al-'amaliyya fi al-sharī́a al-islāmiyya. In Ru'ya Ișlāmiyya li ba'd al-mushkilāt al-tibbiyya al-mu'āsra, ed. 'Abd alRahmānn al-'Awadì and Ahmad al-Jundì, 412-64. Kuwait: Al-Munazzama al-Islāmiyya. li al-'Ulūm al-Tibbiyya.

Watson, James. 1971. "Toward the Clonal Man: Is This What We Want?” The Atlantic Monthly 228:50-53.

Yashyawìi, Muhammad al-. 1997. "Ilā ayn tasìr al-taqniyyāt al-byulūjiyya? Al-Handasa al-wirā thiyya wa al-istinsākh namūdhajan.” In Ru'ya Islāmiyya li ba'd al-mushkilāt al-tibbiyya al-mu'ạsra, ed. 'Abd al-Rahmān al-'Awad̄i and Ahmad al-Jundì, 101-16. Kuwait: AlMunazzama al-Islāmiyya li al-'Ulūm al-Tibbiyya.

Yatìm, Muhammad al-. 1997. "Al-Athār al-ijtimā'iyya wa al-akhlāqiyya li tạtbìq al-istinsākh fi al-majāl al-basharì.” In Ru'ya Islāmiyya li ba'd al-mushkilāt al-tibbiyya al-mu'āssra, ed. 'Abd al-Rahmān al-'Awaḍì and Ạhmad al-Jundì, 227-42. Kuwait: Al-Munazzama alIslāmiyya li al-'Ulūm al-Ṭibbiyya. 